\title{
Difficulties in Mastering and Using English for Specific Purpose (Medical Vocabulary): A Linguistic Analysis of Working Saudi Hospital Professionals
}

\author{
Intakhab Alam Khan ${ }^{1, *}$ \\ ${ }^{1}$ King Abdulaziz University, Jeddah, Saudi Arabia \\ *Correspondence: King Abdulaziz University, Jeddah, Saudi Arabia. Tel: 966-532-013-051. \\ E-mail: ikhan1@kau.edu.sa/dr.intakhab@yahoo.com
}

Received: January 7, 2016

doi:10.5296/ije.v8i1.9163
Accepted: January 24, 2016 Published: March 9, 2016

URL: http://dx.doi.org/10.5296/ije.v8i1.9163

\begin{abstract}
The prime aim and objective of this study was to explore and analyse the difficulties faced by the hospital professionals in knowing and using medical vocabulary (terms) in day to day professional life. It is generally known that English for Specific Purpose (ESP) is different from other general vocabulary courses in many ways. In order to carry out the study, subjects comprised 76 trainees who attended a professional development/training course on the medical terminology. The location of the training course was Jeddah (KSA) which was attended by four types of hospital professionals and trainees. Apart from the personal experience in the past and the current 30 hour-training, a self developed questionnaire was also used to elicit required data. The results of the survey indicated that most of the trainees faced difficulties due to: difficulties in English, Greek and Latin borrowing, difficult word-structure and lack of opportunities to practice. Based on the findings, it could be suggested that the learners should apply some strategies to pursue self-learning via web resource and peer learning.
\end{abstract}

Keywords: English for specific purposes (ESP), medical vocabulary, difficulties, borrowings, web resource 


\section{Introduction}

English for specific purposes (ESP) is usually misunderstood. It is not a subject to be taught and learnt, rather a strategy to acquire specific vocabulary through English as medium of instruction. Administrators, managers and health professionals perceive the urgent need of specific English to help the working staff enhance their level in the given specialties. Studies have been undertaken to explore issues related to learning/teaching of medical vocabulary under the heads of ESP (Robinson, 1991; Salager, 198). Medical vocabulary may present a hurdles even to those who are very good in English, and also to those who can not understand the borrowings from Greek and Latin languages. It has also been noticed that many medical doctors, teachers and working professionals also forget some useful words in due course of time if they don't practice a lot.

Learning, mastering and using medical terms passes through various stages, and ends with proper communication. Similarly, each aspect of medical vocabulary poses great challenges to the neo-learners or even the refreshers. For example, a user faces different kinds and levels of difficulties in various components of medical vocabulary: prefix, root(s) and suffix. In addition, Greek and Latin variables also pose problems in the process of mastering and using medical terms in professional career.

Different kinds of ESP courses are required in all the professional institutions/organisations, therefore medical colleges and hospitals are no exception. The fact that all the medical institutes offer specific course for medical terminology, however, the level of difficulties does not usually allow the learners to attain the conceived targets. Many reasons can be attributed to such learning difficulties. Vocabulary size and variation can be considered as one of the most prominent factors. Difficulties related to learning or using medical terms may be observed in each and every element and skill of English language. It may be connected to the sound system, spelling, grammar(morphology), structure(syntax), vocabulary (lexicon) or meaning (semantics). In this situation, there is a need to design a logically coherent material that can cater to the learners' need and at the same time maintain the standard of learning a subject like medical terms. Then the level of difficulties may better be measured to arrive at a possibly better teaching strategy. In this study, an attempt was made find out difficulties in using and the main factors associated with such difficulties.

\subsection{Aim of the Study}

The ultimate aim of this study was to enable the pedagogues, teachers, professionals and trainees to acquire and assimilate the contents related to medical vocabulary. The study also helps, however to some extent, in directing the researchers and instructors to plan a better and feasible teaching strategy for medical terms.

\subsection{Research Questions}

1. What are the difficulties in using medical vocabulary felt by working professionals at Jeddah-KSA?

2. What are the specific factors associated with the level of difficulties of different groups 
of learners?

\section{Areas of Difficulties}

Each medical term has at least two of the following:

1. Word Root: fundamental meaning of a term

2. Combining Form: an "o" or sometimes other vowels (e, i, or u)

3. Suffix: attached to end of a medical term to modify its meaning

4. Prefix: added in the beginning to alter the meaning

\section{Prefixes:}

Some of the medical terms have prefixes that are the elements attached to the beginning of a word root, however, not all medical words have a prefixes. The following are the popular ones:
Pre-
(before)
Post- (after)

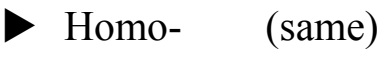
Hypo- (under)
Hyper- (excessive)

In addition to these prefixes, there are many other examples of popular prefixes.(Appendix-B) which also includes certain terms that mean the same and the users are confused between the options: retro-peri, intra-endo, anti-contra etc.

\section{Word roots}

Word roots are the base words. These are also known as the foundation of the word. Most medical terms borrow words or roots either from Greek or Latin languages. These words usually refer to the body parts. It is interesting to note that a medical term can have one or more roots.

The following are some of the common roots:

Examples

Gastr

Cardi

Arthr

Cephal
(Stomach)

(Heart)

(Joint)

(Head) 
$>\mathrm{Cyt}$

- Gyne

Lingua

Thyr

Dent

Dermat

Cardi

Gastr

Pancreat
(Cell)

(Woman)

(Tongue)

(Thyroid)

(tooth)

(skin)

(heart)

(stomach)

(pancreas)

The following word elements list (from Greek and Latin origins) presents complete description with meanings. The difference of the origin creates problems to the users to opt the right choice.

Table 1. Terms having Greek and Latin origin

\begin{tabular}{llll}
\hline \multirow{2}{*}{ Word element } & \multicolumn{2}{c}{ Origin } & examples \\
\cline { 2 - 3 } & Greek & Latin & \\
\hline Stomach & abodomin & Lapara & laprascopy \\
abdomen lapar(o) & abodomin & Laparoscopy artery arteri(o) & Arteriosclerosis \\
blood & haemat & sangui & Hemorrhage \\
& (haem-, hem-) & & \\
brain & encephal(o) & cerebr(o) & Encephalitis \\
breast & mast(o) & mamm(o) & Mastectomy \\
heart & cardi(o) & cordi & Cardiograph \\
kidney & nephr(o) & ren & Nephrology, renal \\
lungs & pneumon & pulmon(i) & Pulmo \\
tooth & odont(o) & dent & Dentist \\
Tongue & gloss, glott & lingu(a) & Glossitis \\
urine, urinary System & ur(o)- & urin(o & Urologist, urinalysis \\
red & erythr(o), rhod(o) & rub, rubr & Erythrocyte, ruby \\
\hline
\end{tabular}

\section{Suffix}

A suffix is added to the end of a word root or combining form to modify its meaning.

By adding a suffix to the end of a word root, we create a noun or adjective with a 


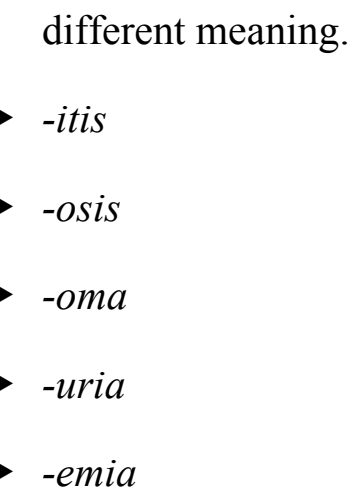

The following is a list of those elements (suffixes) that create great difficulties out of one of more reasons:

Table 2. Suffixes creating difficulties

\begin{tabular}{llll}
\hline Suffixes & Origin & meaning & Terms \\
\hline -cyte & Greek & A hollow, a cell & Leukocyte \\
-ia & Greek & Diseased condition & Insomnia \\
-pathy & Greek & disease or disorder & neuropathy \\
-oma & Latin & Indicating a morbid condition, often a & Carcinoma \\
& & tumor & \\
-plasty & Greek & Denotes surgical repair & Rhinoplasty \\
-tomy & Greek & surgical operation & Appendectomy \\
-plasty & Greek & Surgical operation & Gastroplasty \\
-ectomy & Greek & Removal/cutting & Appendectomy \\
-pexy: & Greek & Surgical fixation & Col/o/pexy: \\
-algia & Greek & Pain & cephalgia \\
-dynia & Greek & Pain & Hepat/o/dynia \\
& & & $=$ hepatalgia \\
\hline
\end{tabular}

\subsection{Pronunciation related issues}

Like general English features, medical words are also pronounced with variations of sounds varying in contexts. The words may be pronounced as these look like following: (febrile $=/ \mathrm{f}$ / sound, begins with /f/). The other category belongs to the words that begin with a letter, or letters that produces the same phonetic sound (physiology $=/ f /$ sound, begins with 
/ph/). Sometimes, a word sounds like /j/ ( as in 'jejunum')while /ge/ = genesis, /gi/ = gingivitis and $/ \mathrm{gy} /=$ gyrus. In addition, it sounds like $/ \mathrm{k} /$ (as in 'kyphosis', /c/ = cornea, /ch/= chorion, 'qu' = quadruplet). Words like pneumonia and knee are peculiar due to silent letters. A word may seem as /z/ (zygomatic) and / $\mathrm{x} /$ (xanthoma). There can be many other words that fall under the specific category that challenge the users of the medical terms.

\subsection{Difficulties in the learning of a branch of medical study}

The following is a list (an example) of the terms pertaining to specific branch (Gastroenterology) that the learners face obvious and greater difficulties in learning them:

Table 3. Difficulties in using Gastroenterology terms)

\begin{tabular}{ll}
\hline & Gastroenterology \\
\hline Organ /term & Causes of difficulties \\
\hline Teeth (Dent/o) & Users are confused which one to choose \\
Teeth (Odont/o) & \\
Tongue (Gloss/o) & Confusion between the two \\
Tongue (Lingu/o) & \\
Gums (Gingiv/o) & Difficulties in pronunciation \\
Jejunum (Jejun/o) & Difficult to pronounce \\
Rectum(Rect/o) & Difficult to choose \\
Anus and rectum(Proct/o) & \\
Gloss/itis: & Confusion between lingual \& glossal \\
Gloss/al: & Why not /ic/ instead of /al/ \\
Lingu/al (adj.): & Why /al/ suffix \\
Sub/lingu/al: & Why sub and hypo same \\
Hypo/gloss/al: & \\
Gloss/o/plegic & Why not linguo-plegic \\
Esophag/eal (adj.): & Why /e/ used before /al/ adjective suffix \\
Dys/enter/y & Why /y suffix \\
Col/o/pexy: & Why/pexy/ and not /plasty/ \\
\hline
\end{tabular}

Taking clues from the above terms, it can be stated that most of the difficulties encountered by the learners/professionals are due to either the Greek or Latin borrowings. In addition, the learners/users don't possess the required proficiency in the target language i.e. English. Other features of difficulties include: use of different terms as an option is available. Words containing double roots also pose difficulties for learners in general. Similarly suffix such as adjectives /al/ or /ic/ create confusion in the selection process. This can be associated with the general English issues. 


\section{Literature Review}

Learning of ESP materials in general plays a vital role in the success of an ESP program. It has been felt that each learner has a specific need of learning in a given perspective. Nababan (1993) pointed out that learner types should be given importance in the process of designing any specific program. In other words, the contents of a program can be selected in accordance with the need analysis.

Munby (1978) felt that ESP materials and syllabus design have a close connection with the linguistic requirements of learners. Teaching of ESP vocabulary is crucial in the pedagogic setting. It is the vocabulary that serves the actual basis for the syllabus structure. According to Widdowson (2000), the fundamentals of ESP program is to conceive the course material for linguistic items.

It has been agreed upon that vocabulary causes main difficulties in the attainment process of the objectives. A comprehensive list of significant vocabulary items as a guide has long been presented for curriculum design, textbook writing and material production. (Jones \& Durrant, 2010). As per the suggestions offered by Huang (2007), the course design along with a textbook-based corpus can enhance reading comprehension in an ESP class. In this regard, Flowerdew (2010) opined that multiple lines of concordance output can explain morphology, context and collocations, and semantics that leads to better understanding.

In other words, these are the terms that incorporate specific meaning in a field, are not used in general English and mostly have Latin and Greek origin (Robinson, 2009,37). Harding (2007, 10-11) is of the opinion that a student can't afford to ignore knowledge of specific terms if he wants to learn and use ESP.

Mićić $(2009,82)$ admitted that all the greatest medical research and innovation have been done in English language. Sinadinović (2013) contended that medical English vocabulary for Academic Purposes is usually considered to be more difficult to learn and use in practice. As regards the contents of the ESP, Brennan \& Naerseen's (1989) work sheds some light on the selection of the topics.

Studies are available in the area of learning difficulties in the area of English in general and medical English in particular, but hardly any study was found in the area of difficulties in the use of medical terms in the professional field of health care. Therefore this study is quite significant because English being the language of medicine is extremely relevant.

\section{Research Methodology}

The present research is of descriptive type following a diagnostic approach to explore difficulty levels and type due to different reasons. The sample was selected purposively as different kinds of trainees were available in an intensive training course under one roof. 


\subsection{Subjects}

The subjects in this study were 76 working hospital professionals/trainees who recently attended a 15 hour professional development program at Jeddah-KSA. The researcher personally experienced the training.

\subsection{Instruments}

\subsubsection{The Questionnaire}

A self developed questionnaire was constructed then employed to elicit the required data. The questionnaire was filled in by the subject of four types: working health professionals, International medical centre (IMC) staff and internship-trainees. The questionnaire includes three scale (agree, undecided, disagree) responses. The items were related to: importance of medical terms, relevance of English for learning medical terms, difficulties caused by the elements: roots, prefixes and suffixes.

\subsection{Data Collection and Analysis}

The questionnaire was administered to the subjects who participated in a professional development program as mentioned earlier.

A total of 76 filled in questionnaires were collected. Then the data were tabulated, graphically presented for each group and analysed as per the need.

\subsection{Validity}

Validity is considered important especially in empirical studies. In descriptive kinds of researches, mostly content validity of the tools/instruments are technically established by seeking opinion on the tools from the area experts to ensure if the tool ( the questionnaire in this context) is valid.

\section{Results and Discussion}

\subsection{Learning Difficulties faced by IMC staff}

Based on the data (Appendix-B) it can be interpreted that $80.3 \%$ of the IMC hospital staff $(80.3 \%)$ agrees that it is important to know medical terms in order to work efficiently in a hospital especially to communicate with the specialists. They $(66.6 \%)$ also stressed the need to possess good English in the background to handle the medical terms. Some staff $(40 \%)$ expressed that they are satisfied with the opportunity to practice medical terms. The response on the item- 8 of the questionnaire indicated that roots are perhaps the most challenging areas with the scenario of learning the medical vocabulary, according to $60 \%$ respondents. 


\section{Il Macrothink}

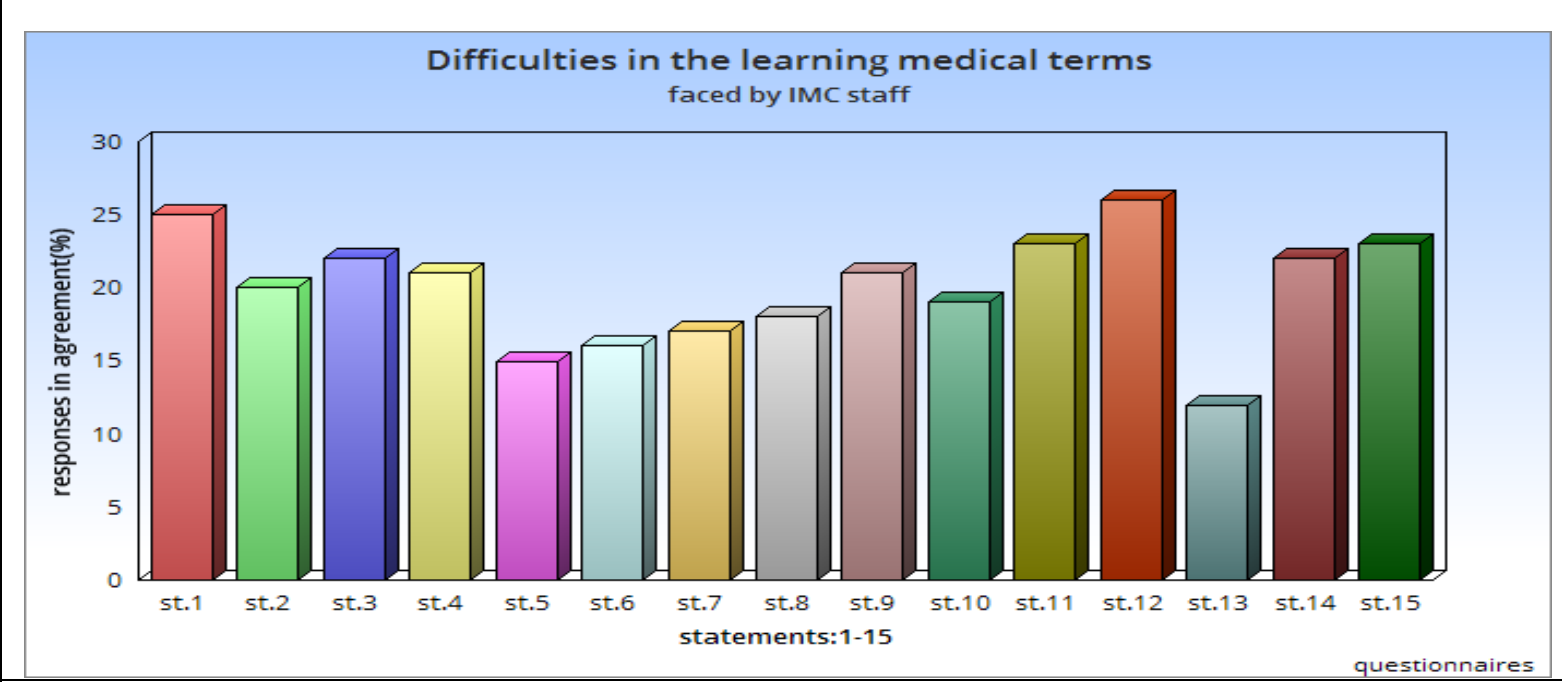

Figure 1. Difficulties in the learning medical terms

\subsection{Learning Difficulties faced by hospital professionals}

The data (Appendix-C) from the other group reflect that most of hospital professionals are in agreement with the fact that the knowledge of the medical terms is essential to work effectively in most hospitals. They also agree that there is an urgent need to have appropriate proficiency level in communicative English to learn medical terms. Many of the hospital professionals expressed their satisfaction with regards to the available opportunities to practice medical terms. The results of the questionnaire indicated that roots are perhaps the most challenging areas with the scenario of learning the medical vocabulary, however, suffixes lead to confusions as well.

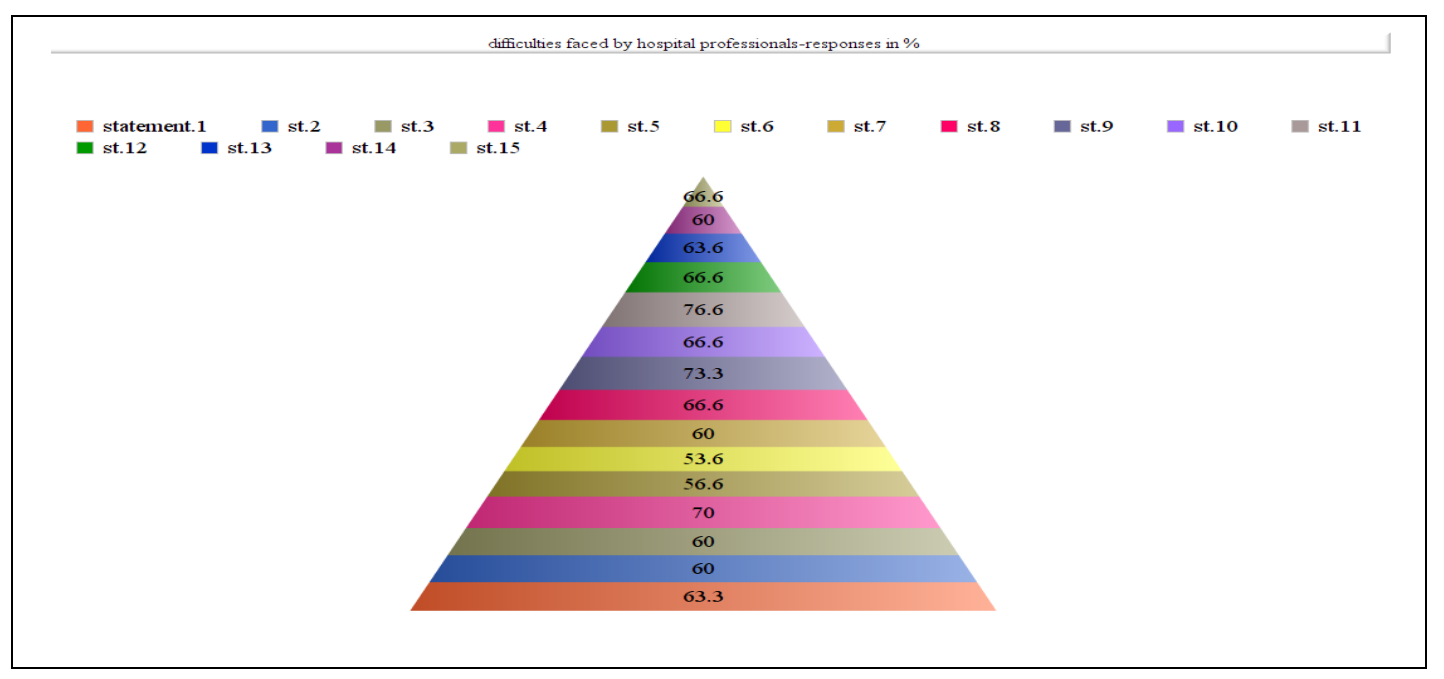

Figure 2. Difficulties faced by hospital professionals-responses in \% 


\subsection{Learning Difficulties faced by trainees}

Data from the questionnaire (Appendix-D) confirm that among the trainees some $85 \%$ of them are of the opinion that Medical terms are important to learn. Some $75 \%$ opine that English should be good to learn medical terms. It is important to learn English in hospitals is the perception of around $80 \%$ trainees. Only $65 \%$ employees confirm that they get some opportunities to practice medical terms in English.

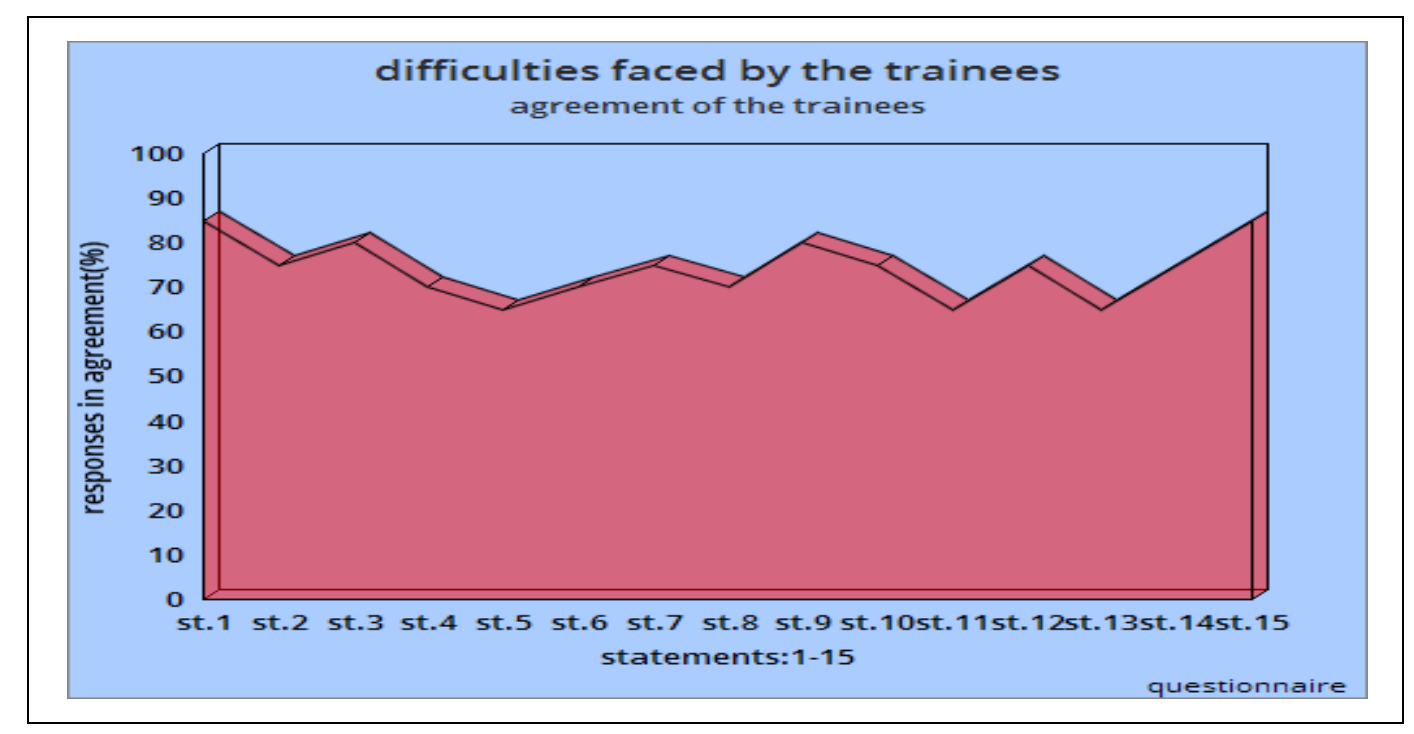

Figure 3. Difficulties faced by the trainees

\subsection{Comparison of the responses}

Appendix -E depicts the comparative data elicited from three different groups. The following item-wise analysis shows the level of agreement on different items:

1- Eighty\% respondents of IMC are of the opinion that medical terms in English are important while $63.3 \%$ other professionals and $85 \%$ trainees feel that medical terms' relevance in the health professions.

2- Good background of English is needed to learn medical terms, feel $66.6 \%$ of IMC staff, but $60 \%$ hospital professionals are positive about having good background of English while $75 \%$ trainees agree on the item.

3- Only 70.3\% IMC staff is in favour of the need of knowing medical terms in hospitals while only $60 \%$ hospital professionals and trainees agree on the issue.

4- $70 \%$ IMC staff, $60 \%$ hospital professionals and $80 \%$ trainees held the opinion that Learning medical terms is very difficult.

5- 50\%IMC staff, 56\% hospital staff and $65 \%$ trainees opine that medical terms are difficult because these are originally nor English, but borrowed from other languages 
like Greek and Latin.

6- In a specific question asked, around 53\% each IMC staff and 61.5\% other working professionals state that many terms have Greek origin while $70 \%$ trainees hold the opinion.

7- There are a few Latin roots, say 56.66\% IMC staff, $60 \%$ hospital professionals, and $75 \%$ trainees respectively.

8- $60 \%$ IMC staff, $76 \%$ professionals and $70 \%$ trainees are of the opinion that Roots are the most difficult to learn.

9- prefixes are easier than the roots, said by $70 \%$ IMC staff, $84 \%$ hospital professionals and $80 \%$ trainees.

10-There are more than one suffixes for similar disease/conditions, stated IMC staff(63.3\%),professionals(76\%)and trainees(75\%).

11- Both the groups of IMC staff and professionals (76.6\%), other professionals(76.6\%), and $65 \%$ trainees are of the opinion that one medical term may include two roots and combining vowels.

12- Practice can make learning of terms easy is the opinion held by $86.6 \%$ (IMC staff), $66.6 \%$ (professionals), and $75 \%$ trainees.

13-40\% IMC staff, $63.6 \%$ professionals and 65\%trainees confirmed that they get enough opportunity to practice terms.

14- Abbreviations also pose problems due to Greek connection is the opinion held by $73.3 \%$ IMC staff, $60 \%$ professionals and $70 \%$ trainees.

15-67.6\% IMC staff, $66.6 \%$ and $85 \%$ suggested that medical books should include medical terms to be specially taught to the students.

\section{Conclusion}

The analysis of data showed that different groups face difficulties in mastering and using the medical terms in English. The aspects in which the difficulties were faced by the participants observed were: the borrowings from Greek and Latin, root words, lack of opportunities etc. Medical terms vocabulary is more difficult than general words due to many reasons. The results also indicated that the two roots and affixes of different types also pose greater issues for the learners/practitioners. It was also found that the abbreviations used in medical field are quite difficult and the connections can't be traced from the English. The three groups varied to some extent on different items of the questionnaire, however, the level of the difference is not that much that attribute to any specific conclusions. It was suggested that the textbooks should include a comprehensive package of medical corpora to learn while pursuing a medical/ paramedical course. It is interesting to note that in almost all the three 
samples' case, the lack of opportunity to practice medical terms has been an issue, however the degree varies.

\section{References}

Brennan, M., \& Van Naerseen, M. (1989). Language and content in ESP. ELT Journal, 43(3), 196-205. http://dx.doi.org/10.1093/elt/43.3.196

Flowerdew, L. (2010). Using a Corpus for Writing Instruction. In O'Keeffe, Anne \& McCarthy, Michael (eds.), The Routledge Handbook of Corpus Linguistics. London/New York: Routledge, pp. 444-457.

Harding, K. (2007). English for Specific Purposes. Oxford: Oxford University Press.

Huang, C.C. (2007). Applying a textbook-based corpus to promote business students' reading comprehension. Paper presented at the Proceedings of International Symposium on ESP \& Its Application in Nursing \& Medical English Education, Kaohsiung, Taiwan.

Jones, M., \& Durrant, P. (2010). What can a corpus tell about vocabulary teaching materials. In O'Keeffe, A., \& Mc Carthy, M. (Eds.), The Routledge handbook of corpus linguistics (pp. 387-400).NewYork: Routledge.

Mićić, S. (2009). Studije o jeziku medicine u engles komisrpskom. Beograd: Beogradskaknjiga.

Munby, J. (1978). Communicative Syllabus Design. Cambridge: Cambridge University Press.

Nababan, P. W. J. (1993). ESP: Materials Preparation in a Foreign Languages Situation.

Robinson, N. (2009). Vocabulary in ESP: Ideas for Bridging the 'Information Gap. Jezikstruke: teorijaipraksa, Zbornikradova. Beograd: Univerzitet u Beogradu, 34 - 42.

Robinson, P.C. (1991). ESPToday: Apractitioner'sguide. Hempstead: Prentice-Hall.

Salager, F. (1983). The lexis of fundamental medical English: Classificatory framework and rhetorical function. Reading in a Foreign Language, 1(1), 54-64.

Sinadinović, Danka. (2013). The importance of strategies in learning and acquiring medical English Vocabulary. JAHR, 4(7), 273-91

Widdowson, H. (2000). On the limitations of linguistics applied, Applied Linguistics, 21, 3-25. http://dx.doi.org/10.1093/applin/21.1.3 


\section{Appendix-A}

(Prefixes causing difficulties for different reasons)

\begin{tabular}{|c|c|c|}
\hline Prefixes & Meanings & words with prefixes \\
\hline Intra & Within & Intravenous \\
\hline Inter & Between & Intercostal \\
\hline Retro- & Behind & Retro sterna \\
\hline Peri & Behind & Perianal \\
\hline Circum & Around & Circumcise \\
\hline Sub & Below & Sub lingual \\
\hline Endo & within, inside & Endoscopy \\
\hline Trans & Through & Transplant \\
\hline Anti & Against & Anti bacterial \\
\hline Contra & Against & Contraceptic \\
\hline $\mathrm{Ab}$ & Away, from & Abnormal \\
\hline A- (an-) & Not, without, -less & Anemia \\
\hline $\mathrm{Ad}$ & To, towards & Adrenal \\
\hline Dys & Bad, not, ill, abnormal & Dysentery \\
\hline Dis & Opposite & Dis-ease $=$ disease \\
\hline Hypo & Less, low, lack & Hypotension \\
\hline Hyper & More, high, excessive & Hypertension \\
\hline Micro & Small & Microscope \\
\hline Macro & Large & Macrocyte \\
\hline Mega & Large & Megacardia \\
\hline Neo & New & Neo natal \\
\hline Ante & Before & Antenatal \\
\hline Pre & Before & Premature \\
\hline Patho & Disease & Pathology \\
\hline Post & After & Post mortem \\
\hline Tox & Poison & Toxin \\
\hline $\mathrm{Re}$ & Again & Relapse \\
\hline Semi & Half & Semi coma \\
\hline Di & Two, double & Diplegia \\
\hline Hemi & Half & Hemisphere \\
\hline Semi & Half & Semi coma \\
\hline Poly & Many & Polyuria \\
\hline Uni & One & Unilateral \\
\hline
\end{tabular}




\section{Appendix-B}

Responses by IMC staff $(N=30)$

\begin{tabular}{|l|l|l|l|l|}
\hline S.N & STATEMENT & Agree & undecided & disagree \\
\hline 1 & Medical terms are important to learn. & $25(83.3 \%)$ & $5(19.2 \%)$ & - \\
\hline 2 & English should be good to learn medical terms. & $20(66.6 \%)$ & $4(13.3 \%)$ & $6(20 \%)$ \\
\hline 3 & Working in hospitals need medical terms. & $22(73.3)$ & $3(10 \%)$ & $5(19.2 \%)$ \\
\hline 4 & Learning medical terms is very difficult. & $21(70 \%)$ & $4(13.3 \%)$ & $5(19.2 \%) \%)$ \\
\hline 5 & $\begin{array}{l}\text { Medical terms are difficult because these are not } \\
\text { English. }\end{array}$ & $15(50 \%)$ & $3(10 \%)$ & $12(40 \%)$ \\
\hline 6 & Many terms are related to Greek origin. & $16(53.3 \%)$ & $7(23.3 \%)$ & $7(23.3 \%)$ \\
\hline 7 & There are a few Latin roots. & $17(56.66 \%)$ & 8 & $5(19.2 \%))$ \\
\hline 8 & Roots are the most difficult to learn. & $18(60 \% \%)$ & $7(23.3 \%)$ & $5(19.2 \%)$ \\
\hline 9 & Prefixes are easier than the roots. & $21(70 \%)$ & $3(10 \%)$ & $6(20 \%)$ \\
\hline 10 & $\begin{array}{l}\text { There are more than one suffixes for similar } \\
\text { disease/conditions. }\end{array}$ & $19(63.3 \%)$ & $6(20 \%)$ & $5(19.2 \%)$ \\
\hline 11 & $\begin{array}{l}\text { One medical term may include two roots and } \\
\text { combining vowels. }\end{array}$ & $23(76.6 \%)$ & $3(10 \%)$ & $4(13.3 \%)$ \\
\hline 12 & Practice can make learning of terms easy. & $26(86.6 \%)$ & $2(6.6 \%)$ & $2(6.6 \%)$ \\
\hline 13 & I get enough opportunity to practice terms. & $12(40 \%)$ & $4(13.3 \%)$ & $14(46.6 \%)$ \\
\hline 14 & $\begin{array}{l}\text { Abbreviations also pose problems due to Greek } \\
\text { connection. }\end{array}$ & $22(73.3 \%)$ & $3(10 \%)$ & $5(19.2 \%)$ \\
\hline 15 & $\begin{array}{l}\text { Medical books should include the terms at the end } \\
\text { of each lesson. }\end{array}$ & $23(76.6 \%)$ & $5(16.6 \%)$ & $2(6.6 \%)$ \\
\hline & & & \\
\hline
\end{tabular}

\section{(Appendix-C) $N=26$}

Responses (for the hospital professionals)

\begin{tabular}{|l|l|l|l|l|}
\hline S.N. & STATEMENT & agree & undecided & Disagree \\
\hline 1 & Medical terms are important to learn. & $19(63.3 \%)$ & $4(15.3 \%)$ & $3(11.5 \%)$ \\
\hline 2 & English should be good to learn medical terms. & $18(60 \%)$ & $3(11.5 \%)$ & $5(19.2 \%)$ \\
\hline 3 & Working in hospitals need medical terms. & $18(60 \%)$ & $5(19.2 \%)$ & $3(11.5 \%)$ \\
\hline 4 & Learning medical terms is very difficult. & $21(70 \%)$ & $1(3.84 \%)$ & $4(15.3 \%)$ \\
\hline 5 & $\begin{array}{l}\text { Medical terms are difficult because these are not } \\
\text { English. }\end{array}$ & $17(56.6 \%)$ & $5(19.2 \%)$ & $4(15.3 \%)$ \\
\hline 6 & Many terms are related to Greek origin. & $16(53.6 \%)$ & $4(15.3 \%)$ & $6(23 \%)$ \\
\hline 7 & There are a few Latin roots. & $18(60 \%)$ & $3(11.5 \%)$ & $5(19.2 \%)$ \\
\hline 8 & Roots are the most difficult to learn. & $20(66.6 \%)$ & $2(7.6 \%)$ & $4(15.3 \%)$ \\
\hline 9 & Prefixes are easier than the roots. & $22(73.3 \%)$ & $1(3.84 \%)$ & $3(11.5 \%)$ \\
\hline 10 & $\begin{array}{l}\text { There are more than one suffixes for similar } \\
\text { disease/conditions. }\end{array}$ & $20(66.6 \%)$ & $3(11.5 \%)$ & $3(11.5 \%)$ \\
\hline
\end{tabular}




\begin{tabular}{|l|l|l|l|l|}
\hline 11 & $\begin{array}{l}\text { One medical term may include two roots and combining } \\
\text { vowels. }\end{array}$ & $23(76.6 \%)$ & $2(7.6 \%)$ & $1(3.84 \%)$ \\
\hline 12 & Practice can make learning of terms easy. & $20(66.6 \%)$ & $3(11.5 \%)$ & $3(11.5 \%)$ \\
\hline 13 & I get enough opportunity to practice terms. & $19(63.6 \%)$ & $2(7.6 \%)$ & $5(19.2 \%)$ \\
\hline 14 & $\begin{array}{l}\text { Abbreviations also pose problems due to Greek } \\
\text { connection. }\end{array}$ & $18(60 \%)$ & $4(15.3 \%)$ & $4(15.3 \%)$ \\
\hline 15 & $\begin{array}{l}\text { Medical books should include the terms at the end of } \\
\text { each lesson. }\end{array}$ & $20(66.6 \%)$ & $3(11.5 \%)$ & $3(11.5 \%)$ \\
\hline
\end{tabular}

\section{Appendix-D}

Responses (for the trainees). $N=20$

\begin{tabular}{|l|l|l|l|l|}
\hline S.N. & STATEMENT & agree & undecided & disagree \\
\hline 1 & Medical terms are important to learn. & $17(85 \%)$ & $1(5 \%)$ & $2(10 \%)$ \\
\hline 2 & English should be good to learn medical terms. & $15(75 \%)$ & $3(15 \%)$ & $2(10 \%)$ \\
\hline 3 & Working in hospitals need medical terms. & $16(80 \%)$ & $1(5 \%)$ & $3(15 \%)$ \\
\hline 4 & Learning medical terms is very difficult. & $14(70 \%)$ & $2(10 \%)$ & $4(20 \%)$ \\
\hline 5 & $\begin{array}{l}\text { Medical terms are difficult because these are not } \\
\text { English. }\end{array}$ & $13(65 \%)$ & $4(20 \%)$ & $3(15 \%)$ \\
\hline 6 & Many terms are related to Greek origin. & $14(70 \%)$ & $3(15 \%)$ & $3(15 \%)$ \\
\hline 7 & There are a few Latin roots. & $15(75 \%)$ & $2(10 \%)$ & $3(15 \%)$ \\
\hline 8 & Roots are the most difficult to learn. & $14(70 \%)$ & $3(15 \%)$ & $3(15 \%)$ \\
\hline 9 & Prefixes are easier than the roots. & $16(80 \%)$ & $2(10 \%)$ & $2(10 \%)$ \\
\hline 10 & $\begin{array}{l}\text { There are more than one suffixes for similar } \\
\text { disease/conditions. }\end{array}$ & $15(75 \%)$ & $2(10 \%)$ & $3(15 \%)$ \\
\hline 11 & $\begin{array}{l}\text { One medical term may include two roots and } \\
\text { combining vowels. }\end{array}$ & $13(65 \%)$ & $4(20 \%)$ & $3(15 \%)$ \\
\hline 12 & Practice can make learning of terms easy. & $15(75 \%)$ & $2(10 \%)$ & $3(15 \%)$ \\
\hline 13 & I get enough opportunity to practice terms. & $12(65 \%)$ & $2(10 \%)$ & $6(30 \%$ \\
\hline 14 & $\begin{array}{l}\text { Abbreviations also pose problems due to Greek } \\
\text { connection. }\end{array}$ & $14(70 \%)$ & $3(15 \%)$ & $3(15 \%)$ \\
\hline 15 & $\begin{array}{l}\text { Medical books should include the terms at the end of } \\
\text { each lesson. }\end{array}$ & $17(85 \%)$ & $1(5 \%)$ & $2(10 \%)$ \\
\hline
\end{tabular}




\section{Appendix-E}

Comparison of the responses:

\begin{tabular}{|c|c|c|c|c|}
\hline \multirow[t]{2}{*}{ S.N. } & \multirow[t]{2}{*}{ Items of the questionnaires } & \multicolumn{3}{|c|}{$\begin{array}{l}\text { Different groups (comparison of the } \\
\text { agreement on items }\end{array}$} \\
\hline & & IMC staff & $\begin{array}{l}\text { Hospital } \\
\text { professionals }\end{array}$ & $\begin{array}{l}\text { Trainees/int } \\
\text { ernship }\end{array}$ \\
\hline 1 & Medical terms are important to learn. & $25(80.3 \%)$ & $19(63.3 \%)$ & $17(85 \%)$ \\
\hline 2 & English should be good to learn medical terms. & $20(66.6 \%)$ & $18(60 \%)$ & $15(75 \%)$ \\
\hline 3 & Working in hospitals need medical terms. & $22(70.3)$ & $18(60 \%)$ & $16(80 \%)$ \\
\hline 4 & Learning medical terms is very difficult. & $21(70 \%)$ & $21(70 \%)$ & $14(70 \%)$ \\
\hline 5 & $\begin{array}{l}\text { Medical terms are difficult because these are } \\
\text { not English. }\end{array}$ & $15(50 \%)$ & $17(56.6 \%)$ & $13(65 \%)$ \\
\hline 6 & Many terms are related to Greek origin. & $16(53.3 \%)$ & $16(53.6 \%)$ & $14(70 \%)$ \\
\hline 7 & There are a few Latin roots. & $17(56.66 \%)$ & $18(60 \%)$ & $15(75 \%)$ \\
\hline 8 & Roots are the most difficult to learn. & $18(60 \% \%)$ & $20(66.6 \%)$ & $14(70 \%)$ \\
\hline 9 & Prefixes are easier than the roots. & $21(70 \%)$ & $22(73.3 \%)$ & $16(80 \%)$ \\
\hline 10 & $\begin{array}{l}\text { There are more than one suffixes for similar } \\
\text { disease/conditions. }\end{array}$ & $19(63.3 \%)$ & $20(66.6 \%)$ & $15(75 \%)$ \\
\hline 11 & $\begin{array}{l}\text { One medical term may include two roots and } \\
\text { combining vowels. }\end{array}$ & $23(76.6 \%)$ & $23(76.6 \%)$ & $13(65 \%)$ \\
\hline 12 & Practice can make learning of terms easy. & $26(86.6 \%)$ & $20(66.6 \%)$ & $15(75 \%)$ \\
\hline 13 & I get enough opportunity to practice terms. & $12(40 \%)$ & $19(63.6 \%)$ & $12(65 \%)$ \\
\hline 14 & $\begin{array}{l}\text { Abbreviations also pose problems due to } \\
\text { Greek connection. }\end{array}$ & $22(73.3 \%)$ & $18(60 \%)$ & $14(70 \%)$ \\
\hline 15 & $\begin{array}{l}\text { Medical books should include the terms at the } \\
\text { end of each lesson. }\end{array}$ & $23(76.6 \%)$ & $20(66.6 \%)$ & $17(85 \%)$ \\
\hline
\end{tabular}

\section{Copyright Disclaimer}

Copyright for this article is retained by the author(s), with first publication rights granted to the journal.

This is an open-access article distributed under the terms and conditions of the Creative Commons Attribution license (http://creativecommons.org/licenses/by/3.0/). 